\title{
Non-capitalist organizations in Latin America: lessons from the Brazilian Faxinal grassroot community
}

\author{
Organizaciones no capitalistas en América Latina: lecciones de los Faxinais, comunidad \\ brasileña de base rural
}

\section{Organizações não capitalistas na América Latina: lições de uma comunidade brasileira de base rural, Sistemas Faxinais}

Fabio Vizeu ${ }^{1}$

Positivo University / Administration MSc and PhD programs, Curitiba - PR, Brazil

Rene Eugenio Seifert ${ }^{2}$

Technological Federal University of Paraná / Management and Economics Department, Curitiba - PR, Brazil

Antônio João Hocayen-da-Silva ${ }^{3}$

Centro-Oeste State University / Administration Department, Irati - PR, Brazil

\begin{abstract}
This essay reveals the foundations of an unconventional form of social organization observed in Brazil's South region, the Faxinal. Methodologically, from the perspective that the Faxinal community embodies a traditional form of organization that has decreased dramatically in recent decades and that many of its original features have changed, we decided to adopt a historical approach. This was a means used to grasp traits and characteristics that, although lost or abandoned, may be instructive regarding the study objectives. Historically, capitalism has taken a position of higher order, by disseminating ideological principles and rationality as possibilities of evolution and better life when compared to the traditional foundations of social organization. The hegemonic view of the dominant model, with determinations imposed by instrumental rationality, pose limits to the richness deriving from the multiplicity of beliefs, traditions, particular customs and practices of the Faxinais, as it supports the generation of ideas and thoughts aimed at maintaining the rationale of development and progress. Thus, substantive organizational phenomena, such as the Faxinais, are situated in a historical process of construction, subject to the local social context of Brazilian regions marginalized by the urbanization and rationalization process of the capitalist economy, which has led their members to devise ways of organizing the social, economic, and political life based on principles different from those that support ideologically the capitalist organizational model. Therefore, the characteristics of the Faxinais point out Unconventional Form of Organization that break with the assumptions of the Organizational Studies.
\end{abstract}

Keywords: Non-conventional management forms. Traditional communities. Social enclaves. Faxinais. Associated human life.

Paper submitted on February 26th, 2014 and accepted for publication on January 14th, 2015.

DOI: http://dx.doi.org/10.1590/1679-395116997

1 Doctor in Management, EAESP/FGV; Adjunct Professor of Business Management at Positivo University. Address: Universidade Positivo - Programa de Mestrado e Doutorado em Administração. Professor Pedro Viriato Parigot de Souza, 5300, Campo Comprido, Code 81280-330, Curitiba-PR, Brazil. E-mail: fabio.vizeu@gmail.com

${ }^{2} \mathrm{PhD}$ in International Management and Organization, The University of Birmingham, England; Assistant Professor at the Technological Federal University of Paraná - UTFPR; Researcher of the Brazilian Institute for Social Studies and Research - IBEPES. Address: Departamento de Gestão e Economia, Universidade Tecnológica Federal do Paraná - UTFPR. Av. Sete de Setembro, 3165, Rebouças, Code 80230-901, Curitiba-PR, Brazil. E-mail: reneseifert@utfpr.edu.br

${ }^{3}$ Doctoral Candidate in Business Management at Positivo University. Assistant Professor at UNICENTRO. Address: UNICENTRO, Departamento de Administração, PR 153, Km 7, Riozinho, Code 84500-000, Irati-PR, Brazil. E-mail: hocayen@yahoo.com.br 


\section{Resumen}

Este ensayo revela los fundamentos de una forma no convencional de organización social que se observa en la región Sur de Brasil, los Faxinais. Metodológicamente, desde la perspectiva de que la comunidad de Faxinais encarna una forma tradicional de organización que ha disminuido drásticamente en las últimas décadas y de que muchas de sus características originales han cambiado, decidimos adoptar un abordaje histórico. Este fue un medio utilizado para captar los rasgos y las características que, aunque perdidos o abandonados, pueden ser instructivos con respecto a los objetivos del estudio. Históricamente, el capitalismo ha tomado una posición de orden superior, mediante la difusión de principios ideológicos y la racionalidad como posibilidades de evolución y mejora de vida en comparación con los fundamentos tradicionales de organización social. La visión hegemónica del modelo dominante, con determinaciones impuestas por la racionalidad instrumental, plantean límites a la riqueza que se deriva de la multiplicidad de creencias, tradiciones, costumbres particulares y prácticas de los Faxinais, ya que apoya la generalización de ideas y pensamientos dirigidos a mantener la lógica de desarrollo y progreso. Fenómenos organizativos sustantivos, como los Faxinais, están, así, insertados en un proceso histórico de construcción, con sujeción al contexto social local de las regiones brasileñas marginadas por el proceso de urbanización y racionalización de la economía capitalista, lo que ha llevado a sus miembros a idear formas de organización de la vida social, económica y política basadas en principios diferentes a los que apoyan ideológicamente el modelo de organización capitalista. Por lo tanto, las características de los Faxinais señalan Formas No Convencionales de Organización que rompen con los supuestos del pensamiento científico dominante de los Estudios Organizacionales.

Palabras clave: Formas no convencionales de organización. Comunidades tradicionales. Enclaves sociales. Faxinais. Vida humana asociada.

\section{Resumo}

Este ensaio revela as bases de uma forma de organização não convencional encontrada no Sul do Brasil, os Faxinais. Metodologicamente, sob a perspectiva de que a comunidade de Faxinal engloba uma forma tradicional de organização que têm diminuído drasticamente nas últimas décadas e de que muitas de suas características originais têm mudado, decidimos adotar uma abordagem histórica. Esse foi um meio utilizado para apreender traços e características que, apesar de perdidos ou abandonados, podem ser instrutivas quanto aos objetivos do estudo. Historicamente, o capitalismo tem adotado uma posição de ordem superior, disseminando princípios ideológicos e a racionalidade como possibilidades de evolução e melhoria de vida em comparação às bases tradicionais de organização social. A visão hegemônica do modelo dominante, com determinações impostas pela racionalidade instrumental, impõe limites à riqueza resultante da multiplicidade de crenças, tradições, costumes particulares e práticas dos Faxinais, à medida que apoia a generalização de ideias e pensamentos voltados à manutenção da lógica de desenvolvimento e progresso. Fenômenos organizacionais substantivos, como os Faxinais, estão, assim, inseridos em um processo histórico de construção, condicionados ao contexto social local de regiões do Brasil marginalizadas pelo processo de urbanização e racionalização da economia capitalista, o que fez com que seus membros desenvolvessem formas de organização da vida social, econômica e política baseadas em princípios diferentes daqueles que suportam ideologicamente o modelo organizacional capitalista. Portanto, as características dos Faxinais apontam Formas Não Convencionais de Organização que rompem com as premissas do pensamento cientifico dominante em Estudos Organizacionais.

Palavras-chave: Formas não convencionais de organização. Comunidades tradicionais. Enclaves sociais. Faxinais. Vida humana associada.

\section{Introduction}

Although the mainstream literature in Organization Studies announces the existence of many different organizational forms (p. e., MINTZBERG [1995]), we state that they are, in fact, the manifestation of one single model of productive organization based on the capitalist system and on the Anglo-Saxon management thought. 
With its roots in the Eighteenth Century Liberalism, the capitalist organization model has historically invaded different domains of human life (RAMOS, 1981); especially in the public sphere, thus becoming the dominant reference of social organization. Peter Drucker's (1992) concept of social profit in the Third Sector and the managerialist model of the 'New Public Management' (DUNLEAVY and HOOD, 1994) are good examples of such invasion. Putting it in a very simple way, we call this monolithic form of organization as Capitalist Organization.

By assuming our Latin American condition and aiming to contribute to a de-colonized perspective in management and organization studies, we state that it is imperative to start paying more attention to our own local knowledge and history in order to better understand organization modes that go beyond the prevalent instrumental form of organizing and theorizing (RAMOS, 1981). In the Latin American context, a goof source of knowlegde is the focus on resistance organization forms and the struggles against the capitalist imperialism.

Many Latin American Non-Capitalist Organizations (NCO) emerging mainly in the rural context carry the heritage of pre-Colombian societies hybridized with European and African cultures. These ethnic groups were typically formed in marginalized survival conditions. This is, for example, the case of Brazilian Quilombolas (small communities of ex-slaves), and many other Brazilian agricultural communities founded by peasants and unemployed workers. Most of these settlings have in common the fact that they are inspired by a community sense of work and life. These settlings, after a long period of marginalization, became an ideological form of resisting the capitalist organization mode.

In the current paper, we studied a grassroot form of organization found in the Southern region of Brazil, namely: the 'Faxinal'. We aim to reveal the constituent principles of this non-conventional organization mode pointing towards its consolidation as al mode formed by values of substantive rationality. It emerged from the struggles for land use during the Brazilian Colonial period. It was founded under the perspective of communal subsistence in harmonic exisitance with the preservation of natural resources. More importantly, it opposes the major principles of the modern capitalist agricultural organization based on individual production and the exploitive use of the land (LÖWEN-SAHR, 2005).

The Faxinal organization can be distinguished from other forms of community organization in rural areas due to its particular characteristics, namely "the ecological use of natural resources, the encouragement to a community sense of life and the preservation of a common memory" (CAMPIGOTO, 2008, p. 1). Members of Faxinal communities organize themselves around the communal use of territorial spaces delimited by social, economic, environmental and religious aspects. Their relationships give meaning to the principle of communalism, which promotes the pacific coexistence between group members. Economically, the productive work is oriented towards the purpose of subsistence, which distinguishes itself from the capitalist logic of market production. Finally, there is a strong connection with the environment, so that the production practices are guided by a sense of ecologial responsibility and preservation (SAHR and LÖWEN-SAHR, 2009).

In the current paper, we discuss three major principles of the capitalist organization challenged by the Faxinal organization mode, namely: instrumental rationality, economic growth orientation and market competition (SEIFERT and VIZEU, 2011). We state that the investigation of traditional grassroot Latin American communities, such as the Faxinal experience, encompasses a path to knowledge about substantive organizations. Since the seminal text by Ramos (1981), substantive organizations have been widely studied in Brazil. It is part of the effort to continue the work by Alberto Guerreiro Ramos intitially undertaken by Serva $(1993 ; 1996 ; 1997)$. Studies on substantive organizations have been used to criticize the hegemony of instrumental rationality as the major reference for articulating organizational activity in the context of emergence management emergence as a fundamental practice of social life in modernity (VIZEU, 2010; 2011). The argument by Notably, Ramos (1981) on a new reference to the organizational theory was based on his readings about the Weberian concept of substantive rationality. 
In Brazil, the theoretical framework informing the study of substantive organizations has been underpinned by the attempt to link particular modes of social action and, therefore, organizational manifestations to the role of substantive rationality. Empirical studies interested in the topic have reinforced the idea that it is possible to find alternatives to the instrumental-market-centered-capitalist organization mode, since the doctoral thesis published by Serva (1996). Substantive organizations are seen by Alberto Guerreiro Ramos' successors as a form of resistance by the civil society when it faces the contradictions of a market-centered life (SERVA, 1993), although these studies point out the difficulties encompassing the efforts to organize the basis of an alternative rationality in the context of an utilitarian market economy.

Although studies on substantive organizations have contributed much to our knowledge on forms of resistence and alternative organization modes, they have been mainly focused on organizational experiences located in urban and industrial contexts. Moreover, studies about substantive organizations have investigated formal organizations, i.e., organizations typicaly taken under consideration by the American Organizational Theorists of the mid-twentieth century such as Blau and Scott (1978). In other words, although such studies considered alternative industries and nonprofit organizations, their object of study considered organizations formally established within modern institutional principles. Ultimately, traditional grasroot experiences have been largely bypassed or disregarded as legitimate organization modes to investigate substantive rationality.

It is important to recognize that traditional grasroot organization modes can encompass historical expressions of resistance to the modern capitalist organization mode, as well as social spaces for nurturing alternatives to the dominant organizational model. In Brazil, several studies have enhanced our knowledge about traditional communities, among them: Diegues (1997), Guarim (2000), Diegues and Viana (2004), Batista (2005), Lima and Bozzobon (2005), Mafra and Städtler (2007) Andreoli (2009), Brandenburg (2010), Cañete and RavenaCañete (2010), Colaço and Sparemberger (2010), Amarante (2011) and Grzebieluka (2012). In the current paper, we look at the Faxinal experience as a means of improving the knowledge on substantive organization modes, considering Ramos (1981) claim that new references are necessary to think about alternative ways for organizing human life.

In the next section, we present the research method used in our investigation and discuss the meaning of 'Faxinal' concept. It is followed by a review about the historical genesis of Faxinal communities. The subsequent section presents the major principles of social organization in these communities. The paper finishes with a discussion and conclusion about what we have learned and how the current study contributes to improve the understanding of non-conventional organization modes.

\section{Research Method}

Vizeu (2008, p. 17) points out that "in Brazil, local researchers face the challenge of understanding the uniqueness of organizational practices in the country performed in a context significantly different from that which constitutes the vast majority of management models adopted here". Notably, Brazil has numerous grassroot and traditional communities (eg.: Fundo de Pasto, Faxinais, Quilombos, Indigenous Tribes, Comunidades Ribeirinhas) which way of life and organization principles differ from and challenge the dominant Anglo-Saxon management and organization. These communities are typically seen as underdeveloped, and they encompass a way of life that does not meet the aspirations and parameters of progress and development of the modern western society.

Our decision to study Faxinal communities is firstly related to the fact that they manifest a non-conventional form of management and organization. Therefore, they are relevant for improving decolonization management studies. Secondly, Faxinal communities are one of the prevalent forms of community grassrrot organization in the state of Paraná, namely the state where the authors of the current paper find their major academic links. 
Methodologically, since the Faxinal community encompasses the traditional form of grassroot organization that have drastically declined in recent decades. Many of its original historical characteristics are likelly to have changed. Thus, we decided to historically aproach the object. It was done as a means of apreheending traces and characteristics that, despite the fact that they have been lost or abandoned, could be instructive for the aims of the current study.

The data collection procedure consisted mainly on literature reviews of historiographical and ethnographic works. We surveyed articles published in conference proceedings, research seminars, and academic journals as well as research reports, legal documents and MSc and $\mathrm{PhD}$ dissertations that comprehensively addressed our research object. The sample was built on the 'snowballing' literature principle. The work by Grzebieluka (2010), in which several relevant studies could be furhter identified, was an important starting point. The studies conducted by Chang (1988), Nerone (2000) and Tavares (2008) were also particularly relevant.

Geography, History, Sociology and Anthropology represent (in order of importance) the fields that have put most energy and effort in documenting and understanding Faxinal communities. We have found no study published or conducted in the field of organization studies. The major topics addressed in those studies include: formation, development, transformation, organization principles, land use, cultural aspects, social, environmental and religious meanings, socio-spatial dynamics, gender issues, preservation and revitalization of the land, conflict and territorial dislocation. Efforts put on the review of aspects characterizing the Faxinal community life were relevant to historically reconstructing its organization principles.

\section{The Meaning of Faxinal}

In popular sense, Faxinal means 'thick woods' (mato grosso) (CHANG, 1988). According to Lupepsa and Schörner (2010), it is a term that is commonly used to represent a specific type of vegetation. Its meaning also corresponds to the popular idea of dense vegetation, i.e. when compared with areas of low vegetation or fields, which were the typical reference for the population living in the southern of Brazil. However, etymologically, Chang (1988) points out that 'Faxinal' has a more specific meaning. It refers to a particular kind of field vegetation (undergrowth vegetation) of varied species and slim trees that penetrate the forests. Nevertheless, Faxinal can also refer to a grassroot form of collective organization within a particular territorial boundary. In this respect, Carvalho (1984) suggests that the term Faxinal possibly emerged as a result of the practice of 'cleaning' (faxina in Portuguese) an area of wood or forest surrounding the community territory where livestock could be freely raised.

Accordingly, Faxinal constitutes a form of a characteristic social collective organization in the Brazilian Southern region (FURTADO, CHAVES NETO, DOMINGUES et al., 2003; OLIVEIRA, 2008; PEREIRA and SOCHODOLAK, 2009; SCHÖRNER, 2010). Currently, it is predominant in the state of Paraná, more specifically in the South Central region of the state (SCHUSTER and LÖWEN SAHR, 2009). However, in earlier times, it was also found in the states of Santa Catarina and Rio Grande do Sul (LÖWEN SAHR, 2005; LÖWEN SAHR and CUNHA, 2005; TAVARES, 2008). The importance of Faxinal communities for the local economy can be measured by the interest of the government in regulating this rural organization model.

Decree 3446 published by the state of Paraná in August $14^{\text {th }} 1997$ characterized the Faxinal community in terms of three aspects, namely: i) free livestock husbandry within the boundairies of the communal land, ii) polycultural agricultural production for subsistence and small scale commercialization, and iii) low-impact forest extraction - with special attention to the production and extraction of Yerba Mate tea, Araucaria tree and other regional native species (PARANÁ, 1997). The same decree further established that the Faxinal territories are to be legally recognized as areas of special regulamentarion (Áreas Especiais de Uso Regulamentado - ARESUR) which legal regulations are the same of those found in areas under environmental protection. 
The state law 15,673 , published in November $13^{\text {th }} 2007$, established a fourth aspect, namely the existence of a particular social culture featured by community ties of solidarity and the preservation of traditional social practices (PARANÁ, 2007). This act of law takes into account that Faxinal is "an old socio-spatial form of agricultural farming that has history and culture of its own" (LÖWEN SAHR, 2008).

Despite the utility profile observed in legal rules that characterize Faxinal communities, authors such as Tavares (2008) and Cordeiro (2011) emphasize the subjective character of this traditional organization mode. They point out that what actually characterizes Faxinal is the peculiar social and cultural practices of its members, who are aware of their own identity and recognize themselves as faxinalenses (those who live in the Faxinal) (OLESKO, 2011). In addition, there is certain agreement that the communal use of the land is the major factor characterizing the Faxinal organization (LÖWEN SAHR and CUNHA, 2005; GRZEBIELUKA, 2010).

Areas for planting and pasture are demarcated by fences in the Faxinal organization. Each family member in the Faxinal is responsible for maintaining a specific portion of these areas (PEREIRA and SOCHODOLAK, 2009). Thus, the Faxinal organization represents "a way of inhabiting the world that articulates common use and private appropriation of the land" (BERTUSSI, 2010, p. 10). Some authors further suggested that the following aspects characterize the Faxinal organization: i) integrated use of the land for livestock, agriculture and plant extraction; ii) spatial organization that incorporates the division of the land in terms of communal areas for livestock husbandry, and individual land for planting; iii) preservation, respect and dissemination of traditional practices, customs and values that have historically promoted synergy and cooperation in the group; iv) the existence of a shared history and culture that inspires the formation of different groups; v) the prevalence of a communitarian life distinguished by solidarity and cooperative bonds; and vi) the conscious use of natural resources ruled by values of ecological preservation (LÖWEN SAHR, 2005; CAMPIGOTO, 2008).

\section{Historical Foundations}

The emergence of the Faxinal organization dates back to the mid-1860s and 1870s. At that time, the term was first used to the social organization of a group of peasants (NOVAK and FAJARDO, 2008). Three distinct historical accounts are used to explain its origins, historical formation and consolidation in the state of Paraná (where this form of organization is more proeminent). Each of them will be reviewd in turn.

\section{The Faxinal as an outcome of Indigenous and Jesuit heritage}

A major historical account attributes the origin of the Faxinal organization to the Spanish Jesuit Missions settled in Paraná around the sixteenth century. It is reported that Jesuits' initially intended to promote forms of communitarian life experienced in some parts of Europe. However, underwent a number of adaptations in Brazil, mainly regarding the influence of indigenous peoples and their moral principles, tradition, ethnic and cultural heritage (NERONE, 2000; NOVAK and FAJARDO, 2008; HAURESKO, 2008; LÖWEN SAHR, 2008; GAPINSKI and CAMPIGOTO, 2010). The Guarany tribes were the first Jesuits' established contact with. These tribes occupied small areas of land close to river valleys and loved on hunting, fishing, subsistence agriculture and extractive activities. Their traditional way of living was gradually replaced by the Jesuitic form of organization which included "new agricultural techniques (e.g.: plowing), animal breeding (horses, cattle, sheep and pigs) and the intensificattion of Yerba Mate production" (LÖWEN SAHR and CUNHA, 2005, p. 93).

The intermigle of traditional Guarany practices of land cultivation with the European practices brought by the Jesuits offer elements to explain some of the Faxinal organization features (NERONE, 2000; SAHR and 
LÖWEN SAHR, 2009). On the one hand, the indigenous legacy explains the strong relationship and respect to the land and its natural resources, the fusion of religious beliefs and mysticism, as well as the principles of communitarian life. On the other hand, the legacy of the Jesuit missionaires is linked to particular practices of social organization among families, the institutionalization of the Catholic religion within the community, as well as the introduction of innovative techniques for food production and livestock husbandry.

The historiographic account that links the Faxinal organization and the Jesuit Missions is further supported by the fact that Faxinal organizations did not develop in the following century. Schollars argue that it occurred mainly due to the intensification of the Bandeiras (Scout groups) in the region in the mid 1630s. The Bandeirantes (scouts) are known by their attacks and the destroction they brought to several Jesuit Missions. Thus, they contributed to the disintegration of early social movements considered to be the genesis of Faxinal community organizations. It is only in the $18^{\text {th }}$ century that we see the ressurgence of Faxinal organizations in the region of Campos Gerais. These communities were essentially formed by small groups of families who devoted themselves to subsistence agriculture production, plant extractivism, hunting and fishing (SAHR and LÖWEN SAHR, 2009).

The ressurgence of Faxinal communities in the $18^{\text {th }}$ Century can also be linked to the expansion of path routes of cattle herders called Tropeiros (specific Brazilian group of herdsmen who lead cattle from theSouthern to the Southest region of Brazil for trading purposes). The Faxinal communities were often responsible for provinding supplies to herdsmen and animals as well as to help in gold mining activities in the region (TAVARES, 2005). The Faxinal communities located on forest edges would initially sale their surplus production to drovers and large farms. Later, they would sale it in surrounding cities formed by Tropeiros who had established housing along the pathways of the cattle herders.

A new cycle begun in the history of Faxinal organizations, with the decadence of cattle trading routes in the second half of the nineteenth century. It was caracterized, by the advancement and incursion of large monoculture plantations (mainly Yerba Mate tea), and cattle raising over the territory of Faxinal communities (CHANG, 1988).

\section{Yerba Mate Plantations}

The second historiographic account for the emergence of Faxinal organizations in the South of Brazil associates this form of grassroot rural organization with the ownership of large land areas land by some families. It explains, for instance, why many Faxinal organizations became known by the family name of some landowners, notably: "Faxinal dos Guedes", "Faxinal dos Andrades" and "Faxinal dos Ferreiras". There was the need of human labour for working on the land and producing Yerba Mate in those large farms. These properties would host settling families who were given the right of housing, planting and raising livestock for subsistence, in exchange to their work on the landowner's property, thus featuring a type of feudal relationship. These initiatives are considered to be responsible for the formation of the first Faxinal organizations. Some authors point out that some of these properties, given their size, would hold up to two hundred families that shared the same territory (NOVAK and FAJARDO, 2008). It must be noticed that, despite the shared use of the land by the families, the legal ownership remained in the hands of a single landowner, who was responsible for the social organization of the group. The synergy between the family who owned the land and the families who worked on the land tipically passed through the need to protect the interests of the group and to protect the territory against political and economic pressures put forward by movements of cattle herder (Tropeiros) and Yerba Mate production (GAPINSKI and CAMPIGOTO, 2010).

A sliglty different account for the genesis of the Faxinal organizations is given by Chang (1988). He argues that the need of manpower for working in the plantations of Yerba Mate, specially during the harvesting periods, is the major factor to explain the emergence of Faxinal organizations. Landowners would attract and allow peasant families to settle in their farms and collectivelly use the land, thus forming these communal 
organizations that later became known as Faxinal. Such practice became particularly attractive in the social and economic context where the labor market was unstructured and hiring workers was difficult. By following this point of view, Toledo and Campigoto (2010) argue that the permission for raising livestock and collectivelly using the land would ensure the permanence and subsistence of families between Yerba Mate harvesting periods. From this point of view, Schuster (2007) states that Faxinal results from a mutually benefitial form of organization for both landowners and family workers.

Despite championing the influence of the Jesuit reductions in the constitution of Faxinais, Sahr and Löwen Sahr (2006) emphasize the settlements arising from the social organization of mestizos as defining events that - inserted in the vicinity of Araucaria forests and linked to the Tropeirismo movement in the Campos Gerais region - promoted the emergence of large farms often occupied by a big number of families. The authors highlighted that Tropeirismo lost steam and reached a stage of decay, concomitantly with the arrival of immigrant settlers in the late nineteenth century and early twentieth century. They found similarities between the way of life of mestizos and the traditional contours of the country of origin of those who would be the first faxinais of Paraná State, a group characteristically formed by Ukrainians, Poles and Germans (SAHR and LÖWEN SAHR, 2006). Subsequently, the community form of social organization, the respect for customs and traditions and the strong bond with the land became the inspiration for the multiplication of faxinais in the South Central region of the state.

Nerone (2000) states that the occupation of rural areas in the South Central Region of Paraná, specifically in the city of Rebouças, was enhanced by the arrival of people who fled the region on the border between the states of Paraná and Santa Catarina, a region that hosted the Contested War - an armed conflict between the mestizos of the region and the Brazilian army and focused on the ownership of occupied lands. Families decided to leave and search for safer and more productive lands motivated by the great insecurity in the area. They went to the South Central region of Paraná yerba mate production and to the low extraction in future settlements that became faxinais.

\section{Collectivist Social Movement}

The third point of view able to explain the origins of the Faxinal organization points out to the formation of a collectivist social movement innitiated by native inhabitants of the region. Such movement was later followed by Eastern European immigrants. This account considers that it began with the demarcation of large amounts of land to form collective ownership settlements (NOVAK and FAJARDO, 2008).Authority, in these social arrangements, was mainly constituted by religious leaders known among the members of the community for their healing powers (NOVAK and FAJARDO, 2008).

Brandt and Campos (2008) point out that communities living in areas close to forest edges and big farms were mainly formed by the intermingle of indigenous, white Europeans and black people. Despite this racial heterogeneity, different ethnic groups lived harmoniously in the region. Such groups would form the social basis that constituted the first Faxinal organizations in Paraná and Santa Catarina. In face of the historical socio-economic adversities and the need for adapting and subsisting within local natural conditions, they promoted and developeda unique set of agricultural practices and farming that would give rise to the Faxinal Organization (LÖWEN SAHR and CUNHA, 2005).

Although there is no definitive conclusion, these different historical accounts are of particular relevance to head towards our intention of better understanding the Faxinal principles of organization. It is considered in the next section. 


\section{Faxinal Communities' Organization Principles}

The Faxinal organizations are economically and socially structured by two central aspects, namely: land for planting and land for livestock husbandry. The areas for planting are private spaces where families grow food for their own subsistence, separately from other Faxinal family members. These planting areas are enclosed to avoid the invasion by animals inhabiting the areas used for livestock raising. Traditionally, the practice of separating the land for planting from the land for livestock husbandry was based on the use of fences. However, the "rachões", which are structures made by splinters of pine trees, as well as pine tree logs, were also used. In earlier times, the use of stone walls for delimitating these areas was also commom. In addition, "valões", which are trenches dug in the surroundings of the cropping fields, were also used to prevent livestock access to these areas (BRANDT, 2005).

The lands for livestock husbandry (pasture) are, in turn, of communal use. Faxinal members mainly raise livestock for their consumption, transport and agricultural assistance. Commercialization can also take place - as in the case of pigs. The animals are marked according to the family ownership. In this case, even in case if animals e raised in communal areas, there is no misunderstanding regarding ownership within the community (NEIVERTH and LÖWEN SAHR, 2005; NOVAK and FAJARDO, 2008; BRANDT and FIELDS, 2008).

Agriculture is practiced for the subsistence of the families. Therefore, planting areas are typically small. The largest areas are used in livestock raising, and typically occuppy areas of forests and woods (BRANDT, 2005). The principle of subsistence is central to the Faxinal economy. As Antunes and Sochodolak (2010) point out, since Faxinal cummutities are located in remote rural areas, usually away from large urban centers, the economic foundation in these traditional communities is the value of their production use and not its exchange value. It means that production is mainly measured by the subsistence and the self-sufficiency of individuals and families. Thus, since they are guided by a non-mercantilist economic logic, Faxinal communities manifest a substantive form of organization that opposes the utilitarian rationality dominant in the modern capitalist world.

Lands for livestock husbandry and planting are further distinguished in terms of location.The steepest areas, characterized by high concentrations of organic materials, are used for agricultural production. They are also the areas where the houses of the community members are built. Flater areas, and those near to water courses, characterized by "Capoeira" vegetation and forests of pine trees, are normally demarcated as communal lands for animal husbandry (NOVAK and FAJARDO, 2008; BRANDT, 2007; BERTUSSI, 2009).

A type of barn named "paiol" is commonly built in the surroundings of the houses. It is used as warehouse for tools, agricultural products, food for the animals, as well as necessary materials for the maintenance and improvements of available facilities (BERTUSSI, 2009).

\section{Communality and Non-property Pratice}

The Faxinal organization is based on a code of communality in which rights, duties and obligations regarding protection, maintenance, management and use of the land, are shared and maintained by all community members. According to Saldanha (2005), it establishes the proper identity of the Faxinal. Moreover, it means that becoming a member of the Faxinal implies the acceptance and respect to the customs, values, beliefs, symbols, artifacts, myths and rituals that have traditionally characterized the community.

The Faxinal territory is where the social bonds of synergy and interaction between its members are established. Thus, it is an important element for the group's identity. However, it is essential noticing that the Faxinal territorial area often has a symbolic character. It is not restricted to a predetermined geographic area 
where family members of the community are installed on. The Faxinal territoriality should be understood as the space where communal social, political and economic relationships that characterize the Faxinal community take place. Therefore, it can encompass families and individuals living in the surroundings of the Faxinal, although they are not recognized as its member. It is, for example, the practice of solidary exchanges that, despite the major characteristics of the social exchange among Faxinal members, is extendend to the surrounding families and individuals, who are not counted as Faxinal members, but are included in its territory.

Another important feature of the communality principle that characterizes the Faxinal and that utlimately manifests the non-utilitarian orientation of this mode of socio-economic organization regards the fact that both members who have and have not land areas leave within the Faxinal community area. Both groups are indistinctly integrated to the community and linked to principles of communal living (NOVAK and FAJARDO, 2008; BERTUSSI, 2009).

In addition to the components of Faxinal families coming from different regions and ethnic groups - divided between land owners and non-owners, the non-owners being bigger in number -, the communities, especially in the early days of their inception, had an extremely particular social structure, in which many of their members worked in religious, health and police functions (NOVAK and FAJARDO, 2008).

Many families do not own the land and they are actually inserted into the aggregate dynamics. Faxinal systems constitute the opportunity for those families to survive on crop, as well as to find an atmosphere that leads to the development of a practical Community life in that territory (TOLEDO, 2008). In this sense, the Faxinal systems' non-characteristic property logic is reinforced by Toledo (2008), according to whom the holders of the rights to the land (the "faxinalenses") expressed their concern with the families that do not own rural properties in case the Faxinal becomes extinct.In the context of faxinal communities, the land is seen as a common good of collective use without any attribution of value to private and individual property (SOUZA and BERTUSSI, 2005). "Access to land for this social group was not necessarily a conditioning title of ownership" (SOUZA, 2009, p. 11), the internal logic of the group departs from the practice of agrarian society with institutionalized principles of collective land use. The logic of private property implies conflict with a central element in the definition of faxinal communities: the free access to the land.

It is perceived in the context of Faxinal systems that, due to the collective use of the land, the "principle of solidarity is expressed in a logic in which the figure of the human being becomes more valuable than material objects" (BARRETO, 2008, p. 35). It gives to many families who could not afford the purchase of land the opportunity to settle in rural areas and change their living conditions through the practice of subsistence farming and animal husbandry for work and for their own consumption (ANTONELI, 2011).

However, "the common use of common lands does not make them available to the public, to any citizen or person, but it shares the idea of morality and justice held by the faxinalenses" (RAMOS, 2009, p. 36) which, although questioned by modern society, is seen "as opposed to private property, expanding with the development of the agriculture of the State" (SHIRAISHI NETO, 2009, p. 22).

Brandt (2005) emphasizes that subjectingthe common lands to the principles of private property, a process supported by fencing procedures for extensive agriculture, colonization and exploitation of timber, determines the precarious logic of property which is not essential to the maintenance of the Community peasant way of life typical of Faxinal Systems.

\section{Religiosity, Political and Police Members and the Resistance Movement}

Until the mid-1940s and 1950s, the members of Faxinal communities had no regular participation in official religious institutions. It mainly due to the absence or precarity of the roads. Therefore, the members who 
performed religious activities or healing were representatives of the community. For example this could include, the priest, the chaplain, the "benzedor", and the midwife. According to Nerone (2000), in many communities, the local authority could also be exercised by members playing other roles (e.g.: block inspector), or who manifested leadership skills.

These representatives would be responsible for group organization issues, as well as for keeping order within the community. Political issues were discussed by the members and ruled by principles of consensus, without the existence of a representative or chief officer. Due to the absence of a formal authority, crimes and other incidents that would require police action were resolved by the members themselves without the interference from groups or individuals outside the community. Religious and moral values characterizing the Faxinal community would inform how such matters were supposed to be solved (NOVAK and FAJARDO, 2008).

Thus, religiosity takes a critical role in the life and organization mode of the Faxinal community. On the one hand, it serves as a source of community cohesiveness. On the other hand, it permeates both everyday practice, as well as the actions' organization and planning. Furthermore, it is manifested in the traditions, customs and memory of the Faxinal community (NERONE, 2000; HAURESKO, 2011).

The role of institutions such as religion is key to understand the survival of Faxinal communities. Since they are grounded in relationships of trust and solidarity, they enable the reproduction of traditional customs and values, thus ensuring the perpetuation of a singular mode of rural organization (BARBOSA, 2010). It is noticed that several studies have indicated that many Faxinal communities began as a movement of resistance to the pressures imposed by external institutions aligned to the dominant economic model. They aimed to ensure the continuity of a singular practice of social organization based on principles of community life and subsistence production that have been strongly influenced by religious beliefs (SIMÕES, 2009; BARBOSA, 2010; SCHUSTER, 2010). In these terms, understanding the dynamics between religiosty and organizational life in the Faxinal context requires going beyond conventional explanations based on an instrumental rationality.

The relationship among religiosity, subsistence and social resistance can be further identified in a set of actions, which genesis refers to both the interior and the exterior of Faxinais. Contemporaneously, it can be recognized in the articulation of a movement named Rede Puxirão de Povos e Comunidades Tradicionais which was constituted as a formal association aiming to represent the collective interests and rights of Faxinal communities. By these means, these marginalized groups can collectively and politically manifest their interests, aiming at repositioning human beings at the center of social, economic and political practices rather than in capitalist corporations.

\section{Solidarity and the Practices of 'Mutirão' and Reciprocal Sharing}

The practice of "mutirão", also known as 'puxirão' or 'pitoco' constitutes another organizing principle in the Faxinal community. This practice consists of the joint effort put forward by community members in favor of someone who needs help in performing tasks that require greater physical effort and time. For example, it includes building houses, harvesting, killing large animals, and other activities that require significant effort and work. Therefore, it is a practice that both manifests and reinforces members' social bonds and communality. It is also a practice that creates a cycle of solidarity in which all those who participate in the Mutirão will also be helped in moments of need. Notably, several authors have shown that being helped by the mutirão effort required that those who received help will help other families/members when they need it (NERONE, 2000; BRANDT and CAMPOS, 2008; HAURESKO, 2011). It should be noticed that, although it is a common practice in the Faxinal organization, the practice of mutirão is not unique to these communities and it can be found in different traditional communities both in rural and urban areas (CALDEIRA, 1956). 
Subsistence production is a predominant feature in Faxinal communities. The main agricultural products include the production of rice, beans, corn, potatoes, cassava, and vegetables (SOCHODOLAK and MANEIRA, 2011). Often, the surplus of subsistence production is exchanged among community members as a means of accessing products that were not produced by the family. According to Sochodolak and Maneira (2011), the practice of sharing or giving of meat surplus from pig production also existed in the Faxinal system. This practice was mainly applied among the nearest neighbors and it was guided by the principle of reciprocal sharing. Ultimately, it strengthened the bonds of friendship and fellowship among members. Notably, in earlier times, this practice was reinforced by the absence of modern food preservation technologies such as the refrigerator.

In sum, we learn that Faxinal communities are organized in terms of the private and collective articulation of different spaces (planting and livestock raising), sustained by the principles of communality, religiosity, reciprocal sharing and joint effort put forward for the bennefit of the community. Socially, we see the manifestation of relationships/ties that give meaning to the principle of communality, which enables the coexistence among group members. Economically, the community is oriented towards family subsistence that differs from the utilitarian principle of capital accumulation. Ecologically, we notice strong bonds with nature and environment. Practices of agricultural production, livestock husbandry and extractivism are strongly guided by a sense of responsibility and respect for the natural resources (SAHR and LÖWEN SAHR, 2009).

\section{Discussion}

According to Ramos (1958), the transposition of a rural world into a urban society embeeds the individual in a series of new social relations based on assumptions of economic behaviors which "stimulate individualism, competition, initiative and the interest in higher standards of existence" (RAMOS, 1958, p. 36). Notably, these are the central characteristics of managerial practices in formal organizations. In view of the Faxinal organization characteristics, we believe it is pertinent to discuss the prospects of Organization Studies in relation to the hegemonic and dominant Capitalist mode of management and organization.

It is particularly relevant recognizing that modern organization and management result from a historical period characterized by the rise of the Industrial Revolution and the capitalist mode of production. Thus, it encompasses a social practice that cannot be understood outside the context of an economic utilitarian logic (RAMOS, 1989). Its consequence is the reproduction of market economy ideological assumptions widely legitimated in theoretical frameworks of the field of Organizational Studies by the fact that "no other field of knowledge is more directly related to the understanding of the consequences of modern rationalism than Management studies, precisely, because it has been strongly affected by instrumental rationality" (VIZEU, 2008, p. 164).

According to Ramos (1989), the lack of critical reflections about the scope of the current organizational theory is the central limitation of its theoretical framework. It disregards the multitude of social facts from different organizational contexts in favor of the dominance of an instrumental theorizing. Thus, the mainstream theory in Organizational Studies becomes blind to the singularities of social experiences informed by organization modes not aligned with the dominant one.

Siqueira (2009, p. 9) argues that "symbolic experiences such as love, trust, honesty, truth and selfactualization should not be included within the purview of economic organizations, only intelligible by their functional and rational standards of conduct and communication". Notably, economic organizations are prone to transform human values into economic values, leading individuals to live under the rule of utilitarian interests. In this context, substantive desires and values that typically form the basis of a substantive and reflexive rationality are perceived as inconsistent elements for the continuity and 
development of the modern world. Thus, formal organizations are responsible for standardizing and controlling thoughts and behaviors of human experience.

In these terms, substantive organization modes, such as the one that characterizes Faxinal communities, encompass spaces of rupture with the dominant Capitalist mode of social organization. In these context, social conduct is informed by substantive values beyond the mere utilitarian calculation of means-end relations. Thus, although segregated and marginilized, the rupture with the dominant model must be recognized as a historical, factual and empirical possibility.

Reason, when freely exercised, is responsible for leading human collectivities through a process of active social change in which they become critical-reflective political actors able to define and conduct their actions based on historically-cultured communitarian interests. Conversely, reason, when reduced to the utilitarian calculation that characterizes instrumental rationality, can be easily determined , conditioned and dominated by the purposes of specific social groups. Social action, in this context, is reduced to unconscious reproductions of dominant assumptions, devoid of any kind of critical reflexivity or subjectivity (RAMOS, 1989). As it has been evidenced by Bulgacov and Castiglia (2003) and Barros and Santos (2010), in social contexts dominated by the utilitarian logic of instrumental rationality, human beings become depersonalized, merely reproducing formal behaviors, devoid of any substantive values.

Unlike the dominant instrumental logic, which traps the reflectivity of the subject and determines the limits of the roles that human beings should play in society, the prospect of substantive rationality aims at human liberation. Notably, liberation from the domination of a Capitalist market society in which human beings behave according to diffuse interests in order to fully become beings that act within the parameters of a reflected conduct (RAMOS, 1989; SOUZA, WELLEN, TEIXEIRA et al., 2003). In these terms, as Serva (1993) claims, the perspective of substantive rationality, as opposed to the utilitarian logic that characterizes instrumental rationality, aims at the effective redemption of the human condition. Thus, in the context of a market society, substantive reflexivity becomes a barrier for the achievement of the purposes of the dominant organization mode, since by means of the substantive rationality, the organization can become social arenas marked by consistent links of relationships and interactions, familiarity, authenticity, respect for individuality, dignity, solidarity, sharing, affectivity, as central elements for the maintenance of productive structures (SERVA, 1993; 1996; 1997). These values characterize human life in terms of a substantive rationality and condition human action to ethical and moral principles that contribute to balance personal and social achievements (SERVA, 1993; 1996). Furthermore, they enable the possibility of harmonizing collectively shared interests and rights (SERVA, 1997).

Thus, as Ramos (1989) points out, on the basis of substantive rationality, individuals construct and reconstruct from social interactions, symbols and artifacts that, by agreement, give meaning to human life. In the meantime, relations, interactions, exchanges and shares are multiple due to different people and social contexts. Multiplicity ceases to exist within the market society and conditions, interpretations and symbolic representations to economic interests of capitalist institutions, depriving the subject's power to act on the understanding of the world.

The principles and characteristics informing the Faxinal communities' organization mode align to the principles of the substantive rationality, and they oppose to the dominant logic that characterises organization in the modern western capitalist society. Notably, as our review has indicated, they differ from the utilitarian economic interests present in modern western society and favour values such as communality, religiosity, solidarity and reciprocity.

Interestingly, the emergence and survival of Faxinal communities as a particular form of socio-economic organization seems to be related to the historical marginalization of these communities in face of the advance of the capitalist society (SOUZA, 2009), specially, regarding the capitalist expansion during the nineteenth and twentieth century in Brazil. Thus, marginality, instead of being a problem, was the driving force that 
enabled the formation of a very different form of community organization. As argued by Silva Jr. and Souza (2009, p. 129), "the social invisibility is a major feature characterizing traditional peoples and communities".

It means that, despite being part of a so-called modern society dominated by the logic of instrumental rationality (RAMOS, 1989; ADORNO and HORKHEIMER, 1985), Faxinal communities emerge as a social manifestation of resistance and alterity (LÖWEN SAHR, 2008). In this regard, we notice that Faxinal communities inform a non-conventional form of organization based on the principle of self-sustainable communality of peasant rationality, thus enabling the balance between social and environmental aspects and the low participation in the capitalist market (CUNHA and LÖWEN SAHR, 2005). Our study suggests that this traditional form of community organization distances itself from the dominant organizing principles of the Brazilian capitalism to the point that it is inspired by a substantive form of rationality (RAMOS, 1989). Notably, it is a form of rationality ruled by values such as communality, religiosity, solidarity, reciprocal sharing, deeply embedded in the culture, history and traditions of the Faxinal, therefore opposing to dominant practices of economic mercantilism, individual competition and capital accumulation.

Furthermore, the Faxinal manifests a way of life that balances ecological harmony and acceptance of ethnically different members. Thus, it becomes a healthy and harmonious space where human emancipation, autonomy, subsistence culture and history are concretely articulated. This organizational context establishes the possibility of a social interaction oriented by cooperation and solidarity. Contrary to the rules of individual competition that prevail in a market economy, property is not established as a manifestation of success, status or differentiation in Faxinal communities. Rather, property rights are communaly and equally shared as a means of enabling the subsistence of all community members.

It does not mean denying that this alternative form of organization has not changed or that it is beyond the pressures imposed by the dominant paradigm. For instance, as argued by Santos (2010), the market economy globalization paradigm puts pressure on any alternative form of social organization, both because such configurations do not guarantee the economic growth required by the dominant institution, and because they undermine the ideology of individual success based on private gain, capital accumulation and consumerism. Therefore, alternative forms of organization such as the one manifested by Faxinal communities indicate the possibility of a social organization based on substantive rationality (RAMOS, 1981). At the same time, they are also constantly threatened by the dominant forces that aim to impose the harsh instrumental rationality that characterizes the dominant form of organization.

In this context, some studies have found that, although the process of isolation or marginalization of Faxinal communities became a determining factor in the continuation of this mode of organization in rural areas, contemporaneously, many communities have deliberatedly strengthened their cultural roots and traditions as a means of resisting the advance of external institutions aligned with the dominant economic model, thus ensuring the survival of their own way of life (SIMÕES, 2009; BARBOSA, 2010; SCHUSTER, 2010). It suggests that many Faxinal groups are aware of the constant threat imposed by the dominant order.

Communality emerges from a major foundational principle of the Faxinal communities. As shown before, whereas there are formal owners of geographic areas occupied by Faxinal communities, there are also family members with social right to use the land, but without legal ownership or tenure. Ultimately, the notion of property is abandoned due to the strong communal links formed through productive and social interactions. Therefore, it enables reinforcing the notion of collective organization. Unlike other communality-based alternatives to the dominant model - e.g.: cooperative societies - the discourse of collectivist property as a means of resistance against private ownership is not present in the Faxinal communities. In other words, , the presumption that all participants are owners of a property or a business is absent in the Faxinal Community. Contrary to the principle of communality that characterizes the Faxinal organization, the notion of cooperative societies emphasizes the collective efforts put forward for market competitiveness and profit maximization, which are ultimately absent in traditional Faxinal communities. 
The rupture with the notion of ownership can be further evidenced by the communal way of life that is peculiar to Faxinal Organizations and that extends to surrounding communities and cities. Communal principles inspiring practices of solidarity, friendship, and reciprocal sharing that go beyond the Faxinal community manifest the importance given to the subject as member of a human community (NOVAK and FAJARDO, 2008). It is also underlined by the emphasis on subsistence production practices that disconnect themselves from the utilitarian logic of the market-oriented production. Even in surplus production conditions, the central focus lies on the maintenance of the community manifested in non-commercial exchange practices. In the context of these communities, social exchange is based on friendly relationships that have been historically legitimated by social bonds of interaction among different families.

Finally, environmental preservation can be seen as a critical factor manifesting the rupture of the Faxinal organization with the anthropocentric capitalist order. As it was observed, the productive activity organization is developed in harmony with the natural space. It is manifested in the enclosure of pastures, the non-destructive use of native forests in coordination with livestock husbandry and the cultivation of Yerba Mate, and the preservation of rivers.

Among other factors that distinguish the formal organization mode, traditional communities such as the Faxinal ones consider their organizational dynamics in biodiversity due to the nature, based on their own categories and classifications, which are often linked to traditional knowledge accumulated during the group's existence (MAFRA and STÄDTLER, 2007; BRANDENBURG, 2010). Thus, individuals assume the dependence of their people regarding the factors available in nature, and put into practice a set of skills that value the environmental conservation and protection, which is, in its essence, the core aspect of their subsistence (GUARIM, 2000; BATISTA, 2005; ANDREOLI, 2009; COLAÇO and SPAREMBERGER, 2010). Such characteristic has been recognized by several authors investigating other traditional organizations. Namely, studies counduted by Diegues (1997), Lima and Bozzobon (2005), Cañete and Ravena-Cañete (2010), Colaço and Sparemberger (2010) and Amarante (2011) corroborate the argument that organizational and productive practices of traditional communities respect the rhythm and cycles of nature by considering the finiteness of environmental resources and their limited regeneration capacity.

The maintance of a lifestyle adapted to the geographical and economic characteristics of a region, characteristic of the social practice in traditional communities, enhances the compliance of these communities to environmental resources (DIEGUES and VIANA, 2004; GRZEBIELUKA, 2012). It is possible to recognize that the conscious use of nature by traditional communities reproduces practices tied to their own social interests. They reflect a singular behavior that recognizes the intrinsic limits of nature's cycles (DIEGUES and VIANA, 2004; GRZEBIELUKA, 2012). It ensures the "use of resources by several generations" (DIEGUES and VIANA, 2004, p. 87), and the subsistence of present and future members of the community (DIEGUES and VIANA, 2004).

Based on the findings by Diegues (1997), Lima and Bozzobon (2005), Mafra and Stadtler (2007) and Cañete and Ravena-Cañete (2010), as well as on our own review of the social organization of Faxinal communities, it is possible to conclude that the use of natural resouces by traditional communities is ruled by a substantive rationality which values align with the necessary substistence of their members.

When considering the current ecological crisis, the Faxinal communities' organization mode can inspire our reflection on values and modes of social organization that respect and integrate the environmental preservation. Ultimately, it demystifies the ideological belief that happiness and satisfaction resultexclusively from antropocentric progress and economic development. 


\section{Conclusions}

The complexity that characterizes different and multiple social systems requires that we accept divergent and complementary theoretical frameworks in order to promote satisfactory explanations to the observed phenomena. It would be naive to believe that a single theoretical perspective will be able to elucidate the different and varied types of facts and modes of organization and social production. Different social circumstances and phenomena demand specific ontological and epistemological assumptions to clarify their specificities (RAMOS, 1989).

However, given the particularities of non-conventional organization modes, investigating them becomes a real challenge, specially when considering that the major theories in the field of Organizational Studies show difficulty in theorizing beyond the tenets of formal organizations (RAMOS, 1989). Thus, the dominant theories are very limited in approaching and understanding these singular forms of organizing. Notably, at the same time that these organizations are disconnected from formal and instrumental organization principles, they are designed in the social dynamics of the community's everyday life and thus contingent to its cultural values and history.

As we have mentioned in our discussion, traditional organization modes, such as the one found in Faxinal communities, represent possible and relevant social phenomena to be investigated in the field of Organizational Studies. As our review indicates, their constituent features point towards the role of a reflective substantive reason guiding their practice and organization mode. Therefore, they constitute relevant references pointing out to the need of breaking up with the dominant academic thinking, which has elected the formal capitalist organization as the only possible organizational mode. Ultimately, it is an ideological process that reflects the instrumental rationality, which is dominant in Modern Society (MARCUSE, 1982).

Academic reflections upon the concept of organization, specially those aiming to break up with categories and categorizations currently accepted and reproduced in mainstream studies, contribute to the recognition of the multiplicity of the organizational forms and practices endowed by singularities that make them different from the dominant organization mode. Therefore, greater flexibility in the available theoretical framework may lead to a multiple understanding of social phenomena in the field of Organizational Studies.

Our study has indicated that Faxinal communities encompass a non-conventional organization mode based on traditional and substantive social relationships than encompass all instances of activities conducted by their members. More specifically, Faxinal organization was characterized as a communitarian way of life conditioned by principles and values historically constituted, accepted and shared. The use and management of the territory is ruled by traditional practices linked to agricultural production for subsistence, the maintenance and defense of collective interests aimed at the protection and reproduction of their own communitarian identity.

We herein return to the original question that motivated our interest in studying the Faxinal community as an alternative or non-conventional form of organizing: what can management scholars learn from Faxinal organizations? Firstly, we believe that scholars and managers can recognize that the social organizational practice differs from the dominant mode. Thus, we believe that the Faxinal experience can inspire alternative modes of organization. Secondly, Faxinal members teach us that human nature does not necessarily conform to what is taken for granted in the dominant organization model of the capitalist society. They indicate that collectivist forms of organizing, usually assumed to be primitive, can indeed be more advanced than the prevailing democratic order. Thirdly, this grassroot community offers a solution to our contemporaneous ecological crisis.

Ultimately, it is necessary to think about the possibilities of balancing economic, social and ecological interests in order to move away from the fallacious and ideological discourse of sustainable development that 
characterizes the neoliberal agenda, and to humbly learn from traditional communities, such as the one considered in the current study, the limits implied by the real balance between environmental, social and economic purposes.

Finally, the Faxinal experience shows us that, under the capitalist order, good practices and fruitful wisdom can indeed be lost. Considering that the capitalist system is an invasive system, it is imperative that one must be aware of the imperialist and colonialist interest of dominant forms of management and organization. Historically, capitalism has adopted the position of a superior order, disseminating its false principles and rationality as an evolution and improvement of life in relation to grassroot traditional forms of social organization.

The current study is not a romantic analysis of the principles and practices of the constituent Faxinais. The recognition of contradictions arising from the clash between formal instrumental organizations and substantive organizational phenomena such as Faxinais, lead us to assume the limitations of the theoretical framework existing in the field of organizational studies, and to rescue conceptual reflections with multiple and inclusive visions, which often come from studies relegated by organizations linked to the substantive literature.

\section{References}

AMARANTE, C. B. Reconhecimento Jurídico-Normativo das Populações Tradicionais pelo Estado Brasileiro: Uma Revisão. Enciclopédia biosfera, Goiânia, v. 7, n. 12, p. 1-9, 2011.

ANDREOLI, V. M. Diálogos entre os conhecimentos tradicionais e as práticas conservacionistas da natureza: uma possível abordagem. In: I Seminário Nacional de Sociologia e Política, 2009, Curitiba ... Anais, Sociedade e Política em Tempos de Incertezas, 2009.

ANTUNES, J.; SOCHODOLAK, H. O Faxinal e a narrativa trágica. Revista Tempo, Espaço e Linguagem (TEL), v. 1, n. 1, p. 133-143, jan./jul. 2010.

BARBOSA, T. A. Estruturação familiar e capital social em Faxinais: o caso de Taquari dos Ribeiros - Rio Azul/PR. Dissertação (Mestrado em Gestão do Território). Programa de Pós-graduação em Geografia, Universidade Estadual de Ponta Grossa - UEPG. Ponta Grossa, 2010.

BARROS, M. A.; SANTOS, T. C. Terceiro Setor: racionalidade instrumental ou substantiva? Revista Espaço Acadêmico (UEM), Maringá, v. 10, n. 113, p. 11-18, 2010.

BATISTA, J. L. Conhecimentos Tradicionais: Estudos Jurídicos das Legislações e Convenções no Âmbito Nacional e Internacional. Monografia (Graduação em Direito). Curso de Direito, Universidade Federal do Pará. Belém do Pará, 2005.

BERTUSSI, M. L. Liberdade para criar: um estudo etnográfico sobre os sentidos da territorialidade tradicional e do criadouro comunitário em uma comunidade de Faxinal do Paraná. Dissertação de Mestrado (Mestrado em Antropologia Social), Universidade Federal do Rio Grande do Sul, Porto Alegre, RS, Brasil, 2010.

BRANDEMBURG, A. Do Rural Tradicional ao Rural Socioambiental. Ambiente \& Sociedade, Campinas, v. 13, n. 2, p. 417-428, jul./dez. 2010.

BRANDT, M. Terras de uso comum no Planalto Serrano de Santa Catarina: um estudo sobre a localidade do Campo da Dúvida, atual município de Fraiburgo entre as décadas de 1930 e 1960. Anais do II Simpósio Internacional de Geografia Agrária; III Simpósio Nacional de Geografia Agrária; Jornada Ariovaldo Umbelino de Oliveira, Presidente Prudente, SP, Brasil, 2005. 
BRANDT, M. Memórias e oralidade no acesso e uso da terra em comum no Planalto de Santa Catarina. Anais do IV Encontro Regional Sul de História Oral: Culturas, Memórias e Identidades, Florianópolis, SC, Brasil, 2007.

BRANDT, M.; CAMPOS, N. J. de. Uso comum da terra e práticas associativistas da população cabocla do planalto catarinense. Geosul, Florianópolis, v. 23, n. 45, p. 43-64, jan./jun. 2008.

BUlGACOV, Y. L. M.; CASTIGLA, F. Z. Dialogando com os princípios de uma abordagem substantiva da organização. Revista Psicologia Organização e Trabalho, Santa Catarina, v. 3, n. 2, p. 11-34, jul./dez. 2003.

CALDEIRA, C. Mutirão: formas de ajuda mútua no meio rural. São Paulo: Companhia Editora Nacional, 1956.

CAMPIgoto, J. A. Os faxinais na perspectiva hermenêutica. Proceedings of XI Encontro Regional da Associação Nacional de História. Jacarezinho, Brazil, 2008.

CAÑETE, T. M. R.; RAVENA-CAÑETE, V. Populações Tradicionais Amazônicas: revisando conceitos. In: V Encontro Nacional da Associação Nacional de Pós-Graduação e Pesquisa em Ambiente e Sociedade, 2010, Florianópolis ... Anais, V Encontro Nacional da Associação Nacional de Pós-Graduação e Pesquisa em Ambiente e Sociedade, 2010.

CARVALHO, H. M. Da aventura a esperança: a experiência auto-gestionária no uso comum da terra. Curitiba, 1984.

CHANG, M. Y. Sistema Faxinal: uma forma de organização camponesa em desagregação no centro-sul do Paraná. (Boletim Técnico, 22). Londrina: IAPAR, 1988.

COLACO, T. L.; SPAREMBERGER, R. F. Sociedade da informação: comunidades tradicionais, identidade cultural e inclusão tecnológica. Revista de Direito Econômico e Socioambiental, v. 1, n. 1, p. 207-230, 2010.

CORDEIRO, J. R. As relações de gênero entre faxinalenses nos Faxinais de Mandirituba e Quitandinha (Região Metropolitana de Curitiba - PR). Anais da XII Jornada do Trabalho, Curitiba, PR, Brasil, 2011.

DIEGUES, A. C. Deforestation and livelihoods in the brazilian Amazon. São Paulo: USP/NUPAUB, 1997.

DIEGUES, A. C.; VIANA, V. M. Comunidades Tradicionais e Manejo dos Recursos Naturais da Mata Atlântica. São Paulo: Hucitec/NUPAUB/CEC, 2004.

DRUCKER, P. F. Managing the non-profit organization: principles and practices. New York: Harper Collins Publishers, 1992.

DUNLEAVY, P.; HOOD, C. From old Public Administration to New Public Management. Public Money \& Management, v. 4, n. 3, p. 9-16, 1994.

FURTADO, E. M. et al. Ranqueamento de faxinais do Estado do Paraná através da análise fatorial. Revista Ciências Exatas e Naturais, v. 5, n. 1, p. 85-99, jan./jun. 2003.

GAPINSKI, I.; CAMPIGOTO, J. A. A dança de São Gonçalo nos faxinais de Rio Azul/PR. Revista Tempo, Espaço e Linguagem (TEL), v. 1, n. 3, p. 43-69, set./dez. 2010.

GRZEBIELUKA, D. Comunidades de Faxinal e suas dinâmicas sócio-espaciais: da formação à degradação de uma tradição no município de Tibagi (PR). Dissertação de Mestrado (Mestrado em Geografia), Universidade Estadual de Ponta Grossa. Mestrado, Ponta Grossa, PR, Brasil, 2010.

GRZEBIELUKA, D. Por uma Tipologia das Comunidades Tradicionais Brasileiras. Revista Geografar (UFPR), Curitiba, v. 7, p. 116-137, 2012.

GUARIM, V. L. M. S. Sustentabilidade Ambiental em Comunidades Ribeirinhas Tradicionais. In: III Simpósio Sobre Recursos Naturais e Sócio-Econômicos do Pantanal, 2000, Corumbá ... Anais, III Simpósio Sobre Recursos Naturais e Sócio-Econômicos do Pantanal, 2000. 
HAURESKO, C. Terras de Plantar, Terras de Criar - Sistema Faxinal: Rebouças - 1950-1997. Terr@Plural, Ponta Grossa, v. 5, n. 2, p. 255-260, jul./dez. 2011.

LIMA, D; BOZZOBON, J. Amazônia socioambiental. Sustentabilidade ecológica e diversidade social. Estudos Avançados 54, São Paulo, v. 19, n. 54, p. 45-76, mai./ago. 2005.

LÖWEN SAHR, C. L. Povos tradicionais e territórios sociais: reflexões acerca dos povos e das terras de Faxinal do bioma da mata com araucária. Anais do III Simpósio Nacional de Geografia Agrária - II Simpósio Internacional de Geografia Agrária Jornada Ariovaldo Umbelino de Oliveira - Presidente Prudente, SP, Brasil, 2005 a.

LÖWEN SAHR, C. L. Preservação e revitalização do Sistema Faxinal na região da mata de araucária do Paraná. Revista Conexão UEPG, v. 1, n. 1, p. 42-46, 2005 b.

LÖWEN SAHR, C. L. Os "mundos faxinalenses" da floresta com araucária do Paraná: racionalidades duais em comunidades tradicionais. Terr@Plural, Ponta Grossa, v. 2, n. 2, p. 213-226, jul./dez. 2008.

LÖWEN SAHR, C. L.; CUNHA, L. A. G. O significado social e ecológico dos Faxinais: reflexões acerca de uma política agrária sustentável para a região da mata com Araucária no Paraná. Emancipação, Ponta Grossa, v. 5, n. 1, p. 89-104, 2005.

LUPEPSA, E. C.; SCHÖRNER, A. Organização sócioespacial: faxinalenses e agricultores de Jesuíno Marcondes, Prudentópolis/PR (1987-2007). Revista Tempo, Espaço e Linguagem (TEL), v. 1, n. 3, p. 11-41, set./dez. 2010.

MAFRA, M. S. H.; STADTLER, H. H. C. Etnoconhecimento e Conservação da Biodiversidade em Áreas Naturais e Agrícolas no Planalto Sul Catarinense. In: III Congresso Brasileiro de Sistemas, 2007, Florianópolis...Anais, $3^{\circ}$ Congresso Brasileiro de Sistemas. Universidade Federal de Santa Catarina, 2007.

MARCUSE, H. A ideologia da sociedade industrial: o homem unidimensional. Rio de Janeiro: Zahar, 1982.

MARTINS, A. G. S. Lutar Quando é Fácil Ceder: as Práticas Organizativas da Associação Cultural Jose Martí (SC) e os Limites da Resistência. Dissertação (Mestrado em Administração). Programa de Pós-graduação em Administração, Universidade Federal de Santa Catarina. Florianópolis, 2010.

MINTZBERG, H. Structure in fives: designing effective organizations. New Jersey: Prentice Hall, 1993.

NEIVERTH, N.; LÖWEN SAHR, C. L. Reflexões em torno de políticas e ações governamentais na comunidade faxinalense Taquari dos Ribeiros (Rio Azul/PR). Anais da XVI Semana de Geografia, XI Jornada Cientifica de Geografia e V Encontro do Saber Escolar e Conhecimento Geográfico. Ponta Grossa, PR, Brasil, 2009.

NERONE, M. M. Terras de plantar, terras de criar: sistema Faxinal - Rebouças - 1950-1997. Tese de Doutorado (Doutorado em História e Sociedade), Universidade Estadual Paulista. Doutorado, Assis, SP, Brasil, 2000.

NOVAK, R.; FAJARDO, S. Desintegração e Resistência do Sistema Faxinal em Itapará - IRATI - PR. Revista Eletrônica Lato Sensu, v. 4, p. 1-10, 2008.

OLESKO, G. F. Faxinalenses e faxinais da região metropolitana de Curitiba: a questão das chácaras de lazer no contexto dos conflitos na relação cidade-campo. Anais da XII Jornada do Trabalho, Curitiba, PR, Brasil, 2011.

OLIVEIRA, D. A. de. Faxinais no município de Prudentópolis - PR: perspectivas históricas. Anais do XI Encontro Regional da Associação Nacional de História - ANPUH/PR, Jacarezinho, PR, Brasil, 2008.

PARANÁ. Decreto Estadual no 3.446, de 25 de julho de 1997. Cria as Áreas Especiais de Uso Regulamentado ARESUR no Estado do Paraná e dá outras providências. Curitiba, 1997. Disponível em: <http://tributoverde.com.br/site/modules/mastop_publish/files/files_4900c0362d493.pdf>. Acesso em: 15 de agosto. 2012 . 
PARANÁ. Lei no 15.673, de 13 de novembro de 2007. Dispõe que o Estado do Paraná reconhece os Faxinais e sua territorialidade, conforme especifica. Curitiba, 2007. Disponível <www.constitucional.mp.pr.gov.br/docs/isad/faxinal/leg01.doc>. Acesso em: 15 de agosto de 2012.

PEREIRA, J. D.; SOCHODOLAK, H. Faxinal Marmeleiros: a leitura entre 1930 e 1960. Anais da V Semana de História - História: Espaços Simbólicos - Seminário de Estudos Étnico-Raciais, Irati-PR: Unicentro, PR, Brasil, 2009.

RAMOS, A. G. A redução sociológica: introdução ao estudo da razão sociológica. Rio de Janeiro: MEC, 1958.

RAMOS, A. G. The new science of organizations: reconceptualization of the Wealth of Nations. Toronto: University of Toronto Press, 1981.

RAMOS, A. G. A Nova Ciência das Organizações: uma reconceituação da riqueza das nações. Rio de Janeiro: FGV, 1989.

RAMOS, A. G. A redução sociológica. Rio de Janeiro: Editora UFRJ, 1996.

RAMOS, J. O. Faxinal dos Kruger: as lembranças do seu passado. In: ALMEIDA, A. W. B.; SOUZA, R. M. Terras de Faxinais. Manaus: Edições da Universidade do Estado do Amazonas - UEA, 2009.

SAHR, W. D.; LÖWEN SAHR, C. L. A problemática espaço/território a partir de geograficidades existenciais: as comunidades faxinalenses no Brasil Meridional. Proceedings of XII Encontro de Geógrafos da América Latina, Montevidéu, Uruguai, 2009.

SALDANHA, I. R. R. Espaços, recursos e conhecimento tradicional dos pescadores de manjuba (Anchoviella lepidentostole) em Iguape/SP. Dissertação de Mestrado (Mestrado em Ciência Ambiental), Universidade de São Paulo - USP, São Paulo, SP, Brasil, 2005.

SCHMITZ, H.; MOTA, D. M.; SILVA JÚNIOR, J. F. A gestão coletiva de bens comuns: o sistema Faxinal e o manejo florestal comunitário. III Congresso Brasileiro de Agroecologia, Florianópolis, SC, Brasil, 2005.

SCHÖRNER, A. Do Faxinal à cidade: migração e desterritorialização - Irati/PR: 1970-1980. Revista de História Regional, v. 15, n. 1, p. 229-257, 2010.

SCHUSTER, W. T. Articulações entre transformações no uso da terra e (des)agregação no modo de vida: reflexões sobre o Faxinal Saudade Santa Anita Turvo - PR. Trabalho de Conclusão de Curso (Bacharelado em Geografia), Universidade Estadual de Ponta Grossa, Ponta Grossa, PR, Brasil, 2007.

SCHUSTER, W. T. A formação dos Faxinais na região Centro Sul do Paraná. Dissertação (Mestrado em Gestão do Território). Programa de Pós-graduação em Geografia, Universidade Estadual de Ponta Grossa - UEPG. Ponta Grossa/PR, 2010.

SCHUSTER, W. T.; LÖWEN SAHR, C. L. O Faxinal do presente e o Faxinal do passado: transformações no uso da terra no Faxinal Saudade Santa Anita - Turvo/PR. Publ. UEPG Ci. Exatas Terra, Ci. Agr. Eng., Ponta Grossa, v. 15, n. 1, p. 7-18, abr. 2009.

SERVA, M. O fenômeno das organizações substantivas. Revista de Administração de Empresas, São Paulo, v. 33, n. 2, p. 36-43, mar./abr. 1993.

SERVA, M. R. Racionalidade e organizações: o fenômeno das organizações substantivas. Tese (Doutorado em Administração). Programa de Pós-Graduação em Administração, Fundação Getúlio Vargas - EAESP/FGV. São Paulo: EAESP/FGV, 1996.

SERVA, M. A racionalidade substantiva demonstrada na prática administrativa. Revista de Administração de Empresas, São Paulo, v. 37, n. 2, p. 18-30, Abr./Jun. 1997. 
SIMÕES, W. Comunidades tradicionais de Faxinais e gestão de políticas públicas educacionais no Estado do Paraná: compreendendo territórios e territorialidades. Dissertação (Mestrado em Gestão do Território). Programa de Pós-graduação em Geografia, Universidade Estadual de Ponta Grossa - UEPG. Ponta Grossa, 2009.

SIQUEIRA, G. M. V. A Racionalidade Substantiva demonstrada na Prática Administrativa: Estudo de Caso "Bando Árvore Sagrada". Monografia (Graduação em Administração). Departamento de Administração, Universidade Federal de Santa Catarina. Florianópolis, 2009.

SOCHODOLAK, H.; MANEIRA, R. Os faxinais na região de irati na década de 1940: a força de uma cultura tradicional. Anais do XI Congresso Luso Afro Brasileiro de Ciências Sociais, Salvador, BA, Brasil, 2011.

SOUZA, W. J.; WELLEN, H. A. R.; TEIXEIRA, J., et al. Entre a racionalidade instrumental e a racionalidade substantiva: estudos sobre o dilema do trabalho cooperativo. In: II Seminário Internacional de Educação Intercultural, Gênero e Movimentos Sociais, Florianópolis ... Anais, Identidade, diferenças e mediações., 2003.

TAVARES, L. A. As formas de propriedade da terra nos faxinais do Paraná. Anais do III Simpósio Nacional de Geografia Agrária - II Simpósio Internacional de Geografia Agrária Jornada Ariovaldo Umbelino de Oliveira, Presidente Prudente, SP, Brasil, 2005.

TAVARES, L. A. Campesinato e os faxinais do Paraná: as terras de uso comum. Tese de Doutorado (Doutorado em Geografia Humana), Universidade de São Paulo, São Paulo, SP, Brasil, 2010.

TOLEDO, I. A.; CAMPIGOTO, J. A. A cultura no sistema Faxinal - comunidade de Marmeleiro de Baixo, Rebouças/PR. Revista Tempo, Espaço e Linguagem (TEL), v. 1, n. 3, p. 71-91, set./dez. 2010.

VIZEU, F. Management no Brasil em perspectiva histórica: o projeto do IDORT nas décadas de 1930 e 1940. Tese de Doutorado (Doutorado em Administração). Fundação Getulio Vargas - FGV/SP, São Paulo, SP, Brasil, 2008.

VIZEU, F. Potencialidades da análise histórica nos estudos organizacionais brasileiros. Revista de Administração de Empresas, São Paulo, v. 50, n. 1, p. 37-47, jan./mar. 2010.

VIZEU, F. Rural Heritage of early Brazilian Industrialists: its Impact on Managerial Orientation. BAR. Brazilian Administration Review, Rio de Janeiro, v. 8, p. 68-85, 2011. 